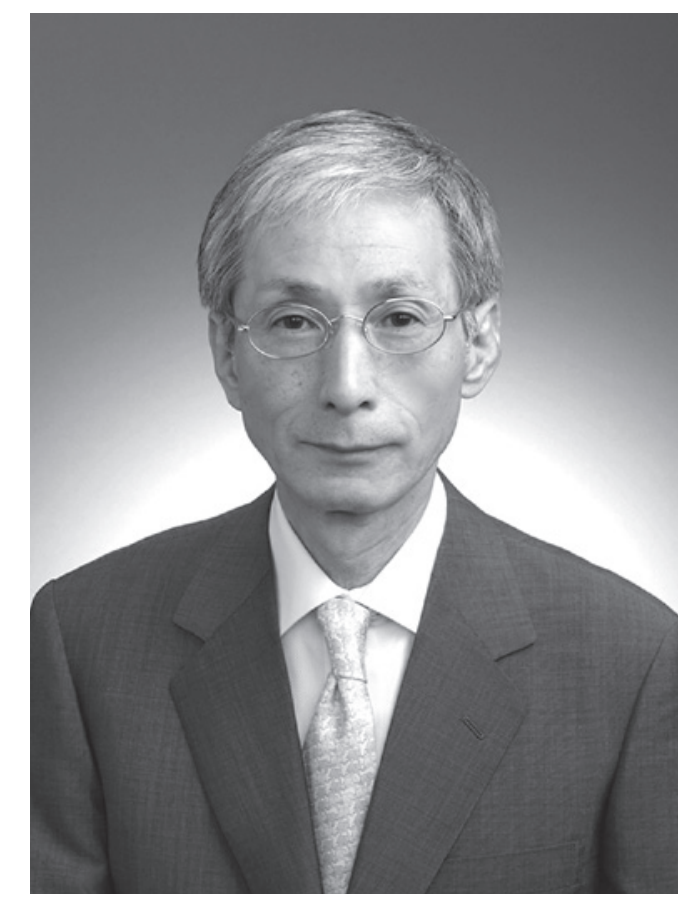

芳 賀 駿 介 大学院教授代行

\title{
略 歴
}

1972 年 3 月 群馬大学医学部卒業

1973 年12月 東京女子医科大学付属第二病院 （現東医療センター）助手

1982 年 4 月 同 講師

1986 年 8 月 同 助教授
2002 年 4 月 東京女子医科大学外科学 教授 東医療センター検査科 部長 2008 年 4 月 日本医科大学外科学講座 教授 日本医科大学付属病院乳腺科 部長 2012 年 4 月 日本医科大学大学院医学研究科 乳腺外科学分野 大学院教授代行

2013 年 3 月 日本医科大学定年退職 


\section{学会役員}

日本乳癌学会 : 理事 (2002年5月～2007年7月)

副会長 (2007年9月～2008年9月)

会長 (2008年10月～2009年7月)

保険診療委員長

乳癌取扱い規約副委員長

日本乳癌学会診療ガイドライン評価委員会委員

\section{主催学会}

第 17 回 日本乳癌学会学術総会

\section{その他}

日本乳癌検診学会 評議員

日本外科学会保険診療委員（臓器別専門小委員会乳腺小委員長）

独立行政法人医薬品医療機器総合機構専門委員 


\section{記念講演会要旨}

\section{日進月歩の乳がん診療}

芳賀 駿介

乳腺外科学

1974 年、群馬大学を卒業し、一般外科医を志して現在の東京女子医科大学東医療センター (旧付属第二病院) に入局しました。当時の一般外科は消化器外科を主としており、乳がんを専門と する体制は敷かれていませんでした。その理由の一つとして当時のわが国の乳がん罹患者数は 約一万人で、女性悪性腫瘍のなかで五番目の罹患者数であったことが挙げられます。しかしその後、 乳がんの罹患者数は生活習慣の欧米化にともない著しく増加し、2005 年の統計では 5 万人を越え、 女性がんの第一位となりました。また、死亡数は 2008 年では約一万人となり、女性がんの死亡 原因の主たるものとなっています。このような社会的背景から乳がん診療は専門性が求められ、 多くの医療機関で乳腺専門の施設が設けられるようになっています。2007 年 4 月、乳がんは他 蔵器がんとは生物学的特性、治療が異なることを日本乳癌学会の理事として主張し、単独蔵器と しては初めて日本医学会加盟が許可され、専門医制度など独立した学会となりました。私が大学を 卒業し、定年を迎える間にこれほどの変貌を遂げたがん専門領域はないと思います。この機会を 利用させていただき、乳がん診療の変遷と私の乳がんとの関わりについて述べたいと思います。

まず、乳がんの治療面からみてみます。医師になった当時は乳がんの手術は乳房と腋窩リンパ 節とともに胸筋を一塊として切除するいわゆるハルステッド手術が標準術式とされていました。 その後、乳がんの生物学的特性が明らかになるにつれ、乳がんの局所とその周辺を大きく切除しても 予後の向上にはつながらないことが証明され、より整容性・QOLに優れた胸筋を温存する胸筋温存 乳房切除術が標準治療となりました。さらに 1980 年代に入り、欧米では乳房を温存し病巣だけを切 除するいわゆる乳房温存療法が行わ机るようになってきました。このころから私は乳がん診療への 興味が増し、乳がんを専門とする外科医になることを決心しました。最初の課題はわが国で乳房 温存療法を行うにあたりその有用性と安全を証明することでした。まず腋窩の小さな創で従来の 腋䆚リンパ節郭清が行えるかどうかを検討いたしました。その結果、乳房温存療法での腋窩郭清は 乳房切除術のそれと同等であることが証明され、腋窩リンパ節郭清に対する問題を解決することが できました。また、わが国に乳房温存療法を導入するにあたり、その適応、方法についての厚生 労㗢科学研究費補助金がん研究事業にも参画し、本治療法の標準化に努めてきました。なかでも 根治性と整容性と相反する要素を満たす過不足のない乳房内の病巣の切除法について研究しま した。それまでは切除緑は手で触れながらの手技でしたが、私は術直前の超音波により切除緑を 色素でマーキングすることでより客観的で、より安全な乳房部分切除術が可能となることを論文に 発表しました。この方法は今でもわが国だけではなく、諸外国でも標準的手技として行われて います。

さらに乳がん治療の進歩は乳がん治療に必須である腋䆚リンパ節郭清についてもなされています。 
腋窩リンパ節郭清は局所治療としてだけではなく、予後を知る上で最も重要なリンパ節転移の 状況をみるために必要な手立てとされています。しかし、腋窩リンパ節郭清は患側上肢のリンパ浮腫や 知覚障害などの後遺症を来たすこと、腋窩リンパ節郭清した患者さんの半数以上に転移がない ことなどから、いかに不必要な郭清を回避できるかが大きな課題でした。1990 年代に乳がん 細胞が最初に到達するリンパ節いわゆるセンチネルリンパ節の存在が明らかとなりました。腋窩に 1-2 個存在するこのセンチネルリンパ節を同定し、転移の有無が分かれば無駄な腋窩リンパ節郭清を 省略することが可能となります。わが国に本手技を導入するにあたり、日本乳癌学会保険診療 委員会の委員長として、高度先進医療制度を用いて多施設共同研究を行い、その安全性を中心に 成績をまとめあげました。わずか一年足らずで全国から一万例を超す症例が集積され、センチルル リンパ節の同定は色素法、RI 法でも 95\% 以上可能であることを分かりました。この研究結果に より、センチネルリンパ節生検の安全性.有用性が証明され、無駄な腋窩リンパ節郭清が省略でき、 患者さんに多大な利益をもたらすこと、入院期間の短縮など医療経済にも貢献できることなどから、 2011 年 4 月保険収載がなされ、いまでは患者さんの生活の質の向上に大きく貢献しています。

乳がんは比較的治りやすいがんの一つとされていますが、比較的早期な乳がんでも転移、再発を きたすものも少なからずあり、乳がん患者さんの約 $1 / 3$ が死亡しています。予後を決定する因子 としてリンパ節転移、核の異型度が挙げられます。そのほかでは、血管新生の程度、最近では 増殖因子の一つである Ki67 の発現の程度なども予後因子とされ、術後薬物療法の適応の決定にも 用いられるようになっています。私は血管新生と転移との関係について血管造影を行い、その腫瘍 濃度と再発との関係を研究し、発表して大きな反響をいただきました。また、1999 年にすでに Ki67 と同じものである MIBI-1 を検索し、その発現の程度と予後が関係することを発表してきました。 現在 Ki67 は乳がんの生物学的特性からみた subtype の一つの因子として見直されていることに 感慨深く思っています。

日本医科大学在籍中にどうしてもやらなければならないものの一つが乳がん患者の半数近くに 行われている乳房切除術後の「人工乳房による乳房再建術」の保険収載でした。独立行政法人 医薬品医療機器専門機構（PMDA）の専門委員として人工乳房を医療機器としての認可をとる ことから始めました。行政、マスコミ、患者団体などへの働きかけの甲斐あって、今年の 9 月に 人工乳房の医療機器としての認可が下りました。現在、厚生労働省で保険点数などの取りまとめが 行われており、中医協を経て近々保険収載される見通しとなっています。長年保険診療に携わって きた私にとって多様化. 個別化する乳がん治療が速やかに医療保険で行える環境を作るという 目標をある程度果たせたと思っています。 


\section{主たる研究業績}

英文

1. The Clinical Value of Tissue Carcinoembryonic Antigen in Breast Cancer

2. Breast Cancer in a Male patient with prolactinoma

3. Relation between Locoregional Hyperthermic Area Detected by Contact Thermography and the Maximum Density of Tumor stain obtained by IV -DSA in Breast Cancer Patients

4. Analysis of the tumor staining obtained by preoperative IV -DSA for breast cancer patients: Density and metastasis correlation

5. MIB1-determined proliferative Activity in Intraductal components and Prognosis of Invasive Ductal Breast Carcinoma

6. Analysis of the tumor staining obtained by preoperativeiv IV -DSA for breast cancer patients: Density and metastasis correlation

7. Prognostic significance of MIB1-determined proliferative activities in intraductal components and invasive fociAssociated with invasive ductal breast carcinoma

8. Antitumor Efficacy of Combination Chemotherapy with UFT and Cyclophosphamide against Human Breast cancer Xenografts in Nude Mice

9. Allelic Loss at the 8p22 Region as a Prognostic Factor in Large and Estrogen Receptor Negative Breast carcinomas

10. Relationship between the morphological characteristics of Intraductal components accompanying invasive ductal breast carcinoma and patient age

11. Mapping of Target Regions of A II elic Loss in Primary Breast Cancers to 1-cM Intervals on Genomic Contigs at 6q21 and 6q25.3

12. Association of Allelic Losses at 3p25.1,13q12, or 17p13.3 With Poor Prognosis in Breast Cancers with Lymph Node Metastasis

13. Monotherapy with paclitaxel as third-line chemotherapy against anthracycline-pretreated and docetaxel-refractory metastatic breast cancer

14. Experience of intravenous digital subtraction angiography(IV-DSA)in evaluation of neoadjuvant chemotherapy for advanced breast cancer

15. Adenocarcinoid of the appendix: report of two cases

16. Phase I study of docetaxel and cyclophosphamide in patients with advanced or recurrent breast cancer

17. Radiotherapy with concurrent docetaxel for advanced and recurrent breast cancer

18. Outcome of breast-conserving therapy in the Tokyo Women's Medical University Breast Cancer Society experience
JAPANESE JOURNAL

OF SURGERY

Surgery Today

Breast Cancer

1996

251-255

33-37

Breast Cancer Research

1997

43

129-135

and Treatment

Jpn. J. Cancer Res

$1997 \quad 88$

$1017-1023$

Breast Cancer Research

199743

129-135

and Treatment

British Journal

1999

79

172-178

of Cancer

ANTICANCER RESERCH

1999

19

1791-1796

Cancer

2000

15

1410-1416

Breast Cancer Research

$2000 \quad 62$

177-184

and Treatment

Jpn. J. Cancer Res

2000

91

293-300

Jpn. J. Cancer Res

200

92

1199-1206

Breast Cance

200

9

166-169

Int $\mathrm{J}$ Clin Onco

2002

322-325

Surg Today

2003

33

375-378

Breast Cancer

2003

10

140-148

Breast Cancer

$2003 \quad 10$

268-274

Breast Cancer

$2003 \quad 10$ 
19. Analysis of ipsilateral breast tumor recurrences

Breast Cancer

2005

12

104-111 after breast-conserving treatment based on the classification of true recurrences and new primary tumors

20. General rules for clinical and pathological recording of breast cancer 2005

21. Ipsilateral breast tumor recurrence (IBTR) after breast-conserving treatment for early breast cancer: risk factors and impact on distant metastases

22. An analysis of factors that influence the duration of suction drainage in breast cancer surgery

Breast Cancer

$2005 \quad 12$

(Suppl)

Cancer

$2006 \quad 106$

S1-27

J Nippon Med Sch

2008

75

332-336

23. Evaluation of sentinel lymph node biopsy in clinically node-negative breast cancer

J Nippon Med Sch

2011

78

96-100 
和文

1. 腋窩リンパ節郭清からみた乳房温存手術の根治 性に関する病理組織学的検討

2. 乳房温存療法の方法および考え方

3. 原発巣の進展形式からみた乳房温存療法の適応 に関する研究

4. 乳癌に対する乳房温存療法の適応と手技

5. 乳癌に対する乳房温存療法 Lumpectomy +腋窩 リンパ節郭清十放射線照射

6. 癌の手術はどう変わったか 病期と乳房温存療法

7. A. 乳腺切除範囲の Pros and cons 2. 乳房温存術式 の功罪

8. 乳癌診療を取り巻く医療保険制度と今後の展望

9. 日進月歩の乳癌の診断と治療
日本外科学会雑詰

乳癌の臨床

日本外科学会雑誌

日本外科学会雑誌

手術

外科

臨床外科

乳癌の臨床

臨床と研究
第 90 巻 第 6 号

第 4 巻 第 4 号

第 91 巻 第 3 号

第 93 巻 第 9 号

第 46 巻第 1 号

第 55 巻 第 12 号

第 54 巻 第 1 号

第 24 巻 第 6 号

第 86 巻 第 3 号
1988

1989

1989

1992

1992

1993

1999

2009

2009

\section{主な成書の監修および編集}

1. 非浸潤性乳管癌の基礎と臨床

2. 悪性と間違えやすい乳腺の良性病変

3. 乳腺の組織型診断とその病態

4. 乳腺疾患 画像診断の進め方

5. 整容性からみた乳房温存治療ハンドブック

6. 非浸潤性乳管癌のすべて
篠原出版新社

篠原出版新社

じほう

じほう

メデイカルサイエンス・

インターナショナル

篠原出版新社
監修

監修

編集

編集

編集

監修
2001

2004

2006

2008

2010

2010 